Tetiana Tenytska,

Sumy State University, Ukraine

Iuliia Myroshnychenko,

Ph.D., Associate Professor, Sumy State University, Ukraine

ORCID ID, 0000-0002-0463-0347

email: myroshnychenko@management.sumdu.edu.ua

Ekaterine Lomia,

Caucasus International University, Georgia

ORCID ID, 0000-0002-3525-6730

email: Ekaterine.lomia@ciu.edu.ge

Correspondence author: myroshnychenko@management.sumdu.edu.ua

\title{
CONFLICT MANAGEMENT SYSTEM IN HEALTH CARE
}

Abstract. This article provides ways to improve the conflict management system in health care based on analyzing the causes of conflicts in a private medical institution. The authors considered the healthcare delivery process in the triad «health worker - patient - society». The study involved analyzing conflict causes in the health care system in the relationship between «health worker - patient» and «health worker - health worker». To determine the conflict causes in private medical institutions and ways to minimize them, the authors used questionnaire data collection, interviewing technique, data analysis, and graphic approach. The study object is medical staff and patients of SILMED Diagnostic Medical Center in Ukraine. The findings identified the main problems in the organization of the conflict management system. Therefore, the essence of conflict situations arising in a medical institution was determined. The obtained results allowed formulating proposals to improve the conflict management system of the private medical institution. Thus, the authors emphasized that the conflict management system in private medicine should minimize the probability of conflict, focus on the treatment quality and the service price. Besides, it should include the development of moral codes for doctors in private medical institutions. The authors noted that to reduce conflict in the relationship «medical worker - medical worker», conflict prevention is more effective than constructive resolution. Thus, conflict prevention requires less effort, resources, and time for a successful clinic operation. To decrease conflicts in the relationship «health worker - patient», it is essential to make a pact between the patient and private medical institution. It establishes the patient's relationship with the clinic and is publicly available for customers. In the study, the authors concluded that during the consultation, the healthcare professional should persuade the patient to follow all recommendations for maintaining or improving the patient's health, requiring, if necessary, evidence from the clinic's patients to follow the treatment protocol.

Keywords: conflict, conflict «health worker - patient, conflict «health worker - health worker», healthcare service, health care, private medicine.

Introduction. The process of establishing and developing private medicine is of particular interest to discuss the problems of national health care. It stands to note that the available information on the private health sector is incomplete. However, private medicine development, as an alternative to the public, is necessary for contemporary society. Notably, the demand for private clinic services is growing rapidly, especially during a pandemic. Thus, a person appeals to a private clinic to save time and avoid queues common to public medical institutions. It is worth mentioning that many people believe that one can count on qualified and quality care if one paid.

However, nowadays, there is no clear regulation controlling the activities of private medical institutions. Besides, legislation aimed at health care, in general, does not offer certain limits and opportunities for private health care development. The legal regulation gaps of the private health sector are reflected not

Cite as: Tenytska, T., Myroshnychenko, Iu., \& Lomia, K. (2020). Conflict Management System in Health Care. Health Economics and Management Review, 2, 61-69. http://doi.org/10.21272/hem.2020.2-07 
only in entrepreneurs but also in health professionals. Sometimes they have differences with patients for various reasons, caused by emotional and psychological characteristics of individuals. Moreover, there is economic and legal influence where the doctor and the private medical organization cannot affect.

The healthcare delivery considers relations in the triad «health worker-patient-society» and various types of social interactions such as cooperation, competition, conflict, etc. First of all, conflict management in private medicine starts with doctors and clinic management. Despite the vast legal framework, the interfacing between health care workers and patients at the level of private health care institutions is often resolved when conflict and offences had occurred. However, administrative decisions in this area should be aimed at preventing ethical and legal conflicts. This study aimed to determine the features of conflict emergence and management in health care, particularly in private medical institutions.

Literature Review. In addition to psychological and physical characteristics, any professional work is based on personal qualities that contribute to the success of the human activity. Foremost, the mentioned above applies to professions where the object of human activity is another person. The type of interaction «person-person» depends on each other qualities. Notably, the profession of a medical worker belongs to complex types of work. The specialist needs continuity training and professionalization, all-around education, erudition, and the possession of personal and professional qualities.

Conflicts in medical institutions are common due to the constant changes and transformations in modern medical organizations and the constant interaction between health professionals (Raykova et al., 2015). Healthcare workers are exposed to numerous psychosocial risks, such as stress at work, burnout, aggression in the workplace, or conflict between work and family (Chen et al., 2017; Portoghese et al., 2017). At the same time, unresolved conflicts among health care workers can lead to complex patient care consequences (Kim et al., 2017; Baldwin and Daugherty, 2008) and have a significant impact on their competence, confidence, and morale (Piryani and Piryani, 2019). Kelly and Al-Rawi (2021) distinguish three primary forms of conflict in the field of health care: conflict of tasks is associated with differences of opinion and opinion; process conflict, which includes differences over methods of achieving results; conflict in the relationship, interpersonal incompatibility between staff, or between staff and the patient/relative of the patient. The results of a survey of Cypriot health workers noted the following causes of workplace conflicts in descending order: high workload, low pay and different guidance from different managers (Pitsillidou et al., 2018). Blanco-Donoso et al. (2021) investigate the specifics of conflicts in global health systems due to COVID-19. Based on the hierarchical analysis, the authors found that daily conflicts between work and family and burnout were significantly related to the intention to leave the profession and decrease the level of daily life energy. Barriers to conflict resolution are lack of time and workload; people in less powerful positions; lack of recognition or motivation to resolve the conflict; and avoid confrontation for fear of causing emotional discomfort (Brown et al., 2011).

It stands to emphasize that the work of medical workers is very responsible. It involves constant excessive psycho-emotional pressure that requires the endurance of medical workers to make medical decisions in extreme situations (Lymar, 2011). In turn, the important principle of medical workers is the collegial solution to the most complex and difficult issues in medical practice and friendly mutual assistance. The medical worker must be fair, honest, recognize and respect colleagues' knowledge and experience, contribute to their profession. Besides, any health worker should be tactful, polite, restrained, calm with other colleagues (Korzh, 2013). In the study (Bylchenko, 2004), the author identified several psychological stressors affecting the medical staff as follows: heightened requirements on the medical worker professional competence, self-sacrifice and service to others; constant contact with sick patients and their families; handling with people's pain of loss and health problems; working environment with many social risk factors, such as drug addiction, alcoholism, crime, etc.; high responsibility for the health and lives of others. To minimize the conflict impact and manage it, it is necessary to determine the subject of conflict in medicine: objective reasons (which do not depend on the doctor); organizational and technical, 
financial (economic); subjective (depending on the doctor); information and deontological, diagnostic, medical and preventive, tactical (Mochalov, 2014).

Methodology and research methods. This study involved questionnaire data collection method, interviewing technique, data analysis and graphic approach to determine the conflict causes in private medical institutions and ways to minimize them. The study object is medical staff and patients of SILMED Diagnostic Medical Center in Ukraine. The authors considered 256 scientific publications indexed in the Scopus database to provide a bibliographic analysis of conflicts in medicine. To visualize the obtained results, the software tool VOSviewer was used.

Results. In this study frame, the authors investigated the directions of scientific publications devoted to conflicts in health care. The data containing bibliographic information on scientific publications in peerreviewed publications were retrieved from the Scopus database. To find the most relative publications, the authors implied key terms such as «conflict» and «healthcare» in the titles of the documents, abstracts and keywords. The obtained results were limited to the subject area «Business, management and accounting». Therefore, the survey sample consists of 256 publications dated from 1985 to 2021. Figure 1 visualizes the network of the thematic directions due to VOSviewer software tools.

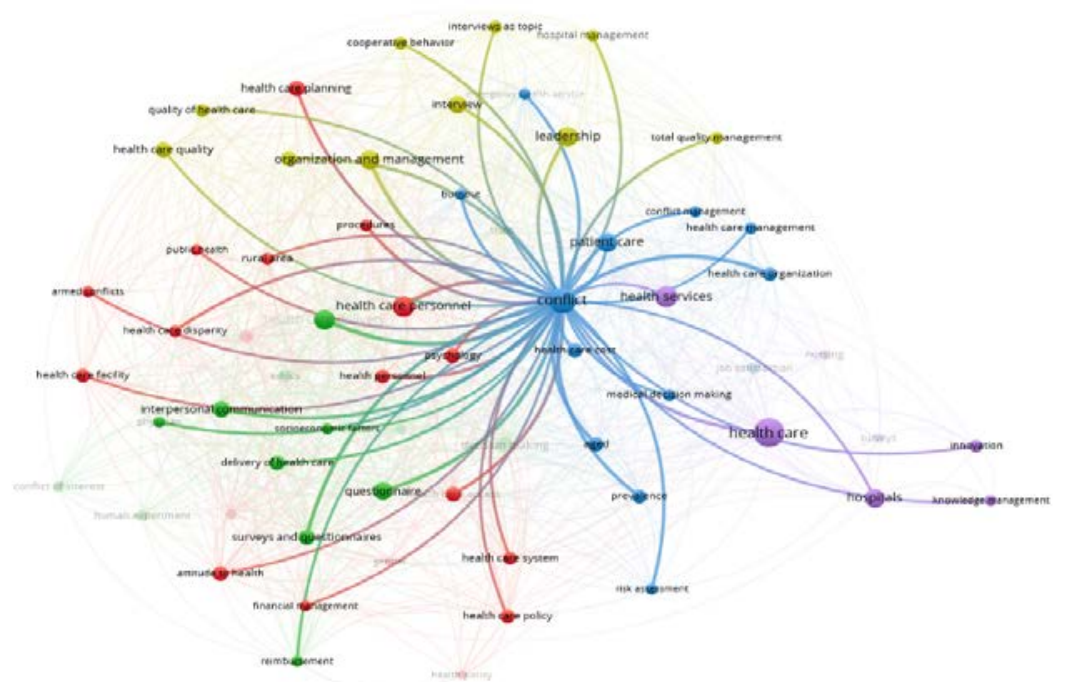

Figure 1. Visualization of term network ( $N=256, f$ (frequency) $\geq 5$ )

Sources: developed by the authors based on Scopus.

Figure 1 confirmed the correctness of using the questionary method to determine the conflict causes in health care under the relationship systems «health worker - patient» and «health worker - health worker». The findings showed that the scientists investigating conflicts in medical institutions mostly devoted their works to study procedures, the price-quality ratio of healthcare delivery, treatment efficacy, interpersonal and age communication, trust, psychology of healthcare delivery, compensation and innovation.

It stands to note that conflict management in private medicine starts with doctors and clinic administration. Despite the vast legal framework, the issues of relationship regulation between medical workers and patients at the level of private medical institutions are often resolved in conflicts and offences 
occurrence. Therefore, administrative decisions in health care should be aimed at preventing ethical and legal conflicts. Figure 2 systematize the parties to the conflict in medical institutions.

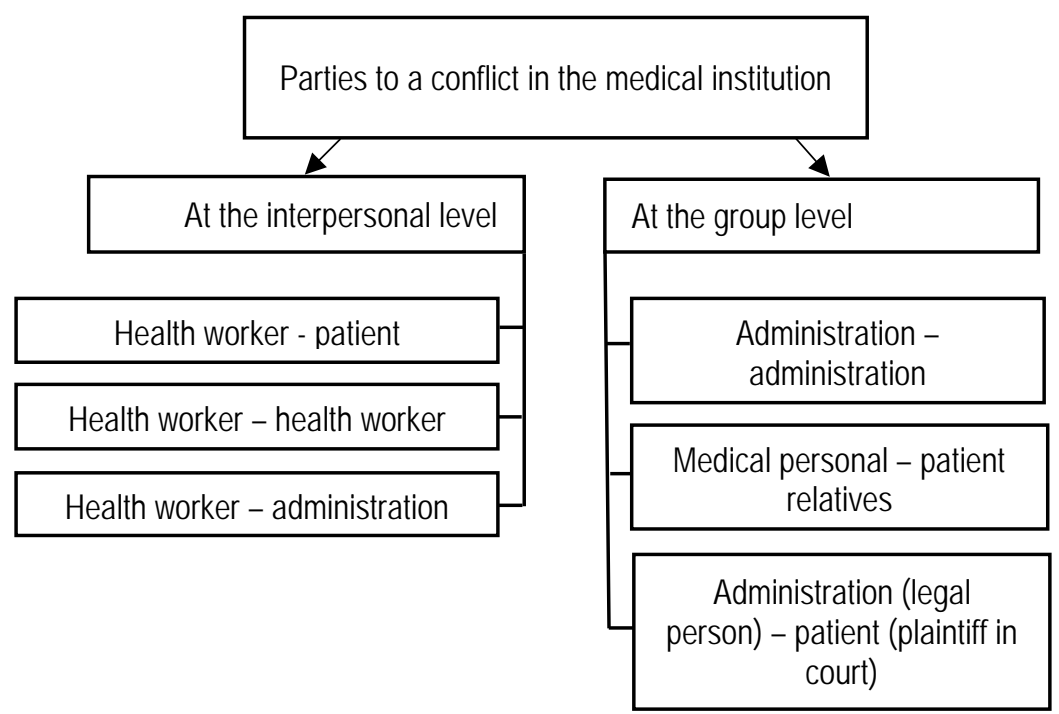

Figure 2. Parties to a conflict in the medical institution

Sources: developed by the authors

Notably, conflicts in private medical institutions can arise at different levels of interaction. At the level of «society - health care», conflict situations between doctors and patients in private clinics occur due to the lack of a holistic and consistent health care development concept. Insufficient financial and logistical support of the health care system also affects the private health care sector because it has objective (declining economy, lack of resources) and subjective (short-sighted, irresponsible state policy) reasons. The medical staff in private medical institutions is dissatisfied with remuneration for their work. Doctors do not always evaluate themselves as equivalent to their pay. Therefore, they look for additional earnings, which affects the work quality.

In turn, special attention should be given to conflict management in the system «health worker patient». In this case, conflicts have resulted from the collision of thoughts, views, ideas, interests, views and expectations. Moreover, conflicts could be caused by the inappropriate perception of the proper behaviour of medical staff (rudeness, impoliteness), procedures (irregularity, unpunctuality), sanitary conditions in the hospital (noise, odour), incorrect diagnosis or incorrect appointment of therapy.

The findings showed that the mismatch in price-quality service and dissatisfaction with the treatment are the main conflict-causing factors in private medical activities that should be minimized. Sometimes patients expectations about the competencies of diagnostic center doctors do not coincide with doctors' perceptions of their social role. In the conflict management system of a private medical institution, there are cases of referring the patient to many specialists and forcing one to pass a huge amount of tests. This attitude divergence conceals the conflict at the micro-institutional level and leads to a further decline in patients' trust in doctors and the health care system.

Identifying conflicts in the private health care sector in the relations «medical worker - patient» and «medical worker - medical worker» was conducted on SILMED Diagnostic Medical Center data (Ukraine). To analyze the conflict management system in SILMED, a survey of the clinic's staff and patients was 
conducted in 2020. The survey provided several stages and consisted of several questionnaires. The survey sample was 35 out of 49 clinic staff and 70 patients (visitors).

Table 1 demonstrates the results of SILMED employees self-assessment. Thus, $52 \%$ of employees consider themselves conflict-free, $29 \%$ - sometimes, conflictory, while 17\% - conflict person. In turn, 2\% of respondents could not answer this question exactly.

Table 1. Conflict assessment between SILMED's medical staff

\begin{tabular}{lccc}
\hline & Characteristics & Number of people & $\%$ \\
\hline Conflict person & 6 & 17 \\
Probably, conflict person & 10 & 29 \\
Conflict-free person & 18 & 52 \\
Difficult to answer & Totally & 1 & 2 \\
\hline & 35 & 100 \\
\hline
\end{tabular}

Sources: developed by the authors based on SILMED's medical staff survey.

The obtained results allowed determining how often SILMED employees were involved in conflicts. Figure 3 shows that $56 \%$ of respondents answered that they sometimes conflict, $12 \%$ - often conflict, $20 \%$ - managed to avoid conflicts. Herewith, $4 \%$ of employees found it difficult to answer this question.

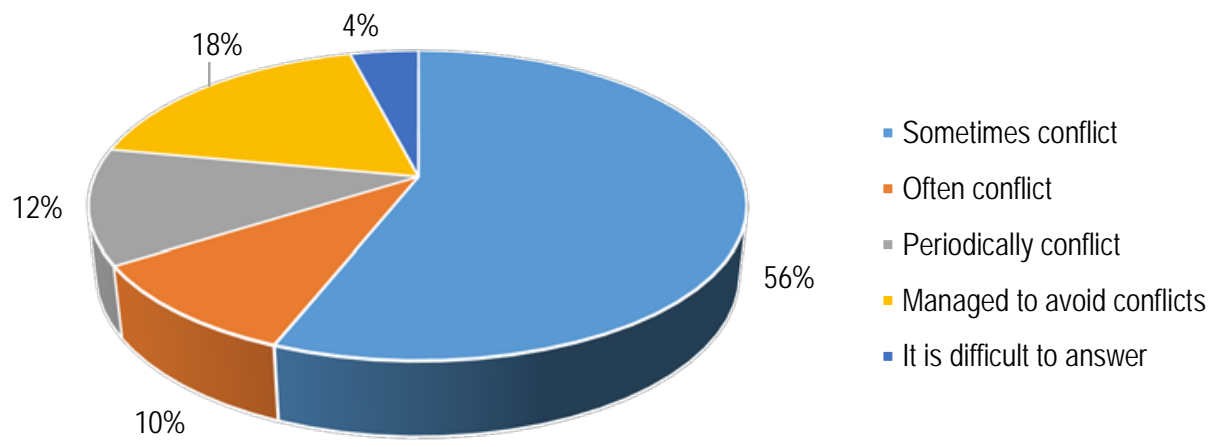

Figure 3. Conflict frequency among SILMED's medical staff

Sources: developed by the authors based on SILMED's medical staff survey.

There were identify the conflict causes among SILMED's medical staff. Thus, Table 2 demonstrates that most conflicts were caused by: work misarrangement (97\%), incompetent managers, including exceeding of authority (85\%) and low sociability (91\%).

Table 2. The conflict causes among SILMED's medical staff (by employees self-assessment)

\begin{tabular}{|c|c|c|}
\hline The conflict causes & $\begin{array}{l}\text { Number of } \\
\text { respondents }\end{array}$ & $\%$ \\
\hline Fight for SILMED property & 0 & 0 \\
\hline Unequal privilege distribution & 5 & 14 \\
\hline Unfair salary & 10 & 29 \\
\hline High ambitions of some workers & 0 & 0 \\
\hline Sociability & 12 & 34 \\
\hline
\end{tabular}




\begin{tabular}{|c|c|c|}
\hline & \multicolumn{2}{|c|}{ Continued Table 2} \\
\hline Courage and confidence & 10 & 29 \\
\hline Work misarrangement & 34 & 97 \\
\hline Incompetent managers (exceeding authority) & 30 & 85 \\
\hline Jealousy among medical stuff & 15 & 42 \\
\hline Low sociability & 32 & 31 \\
\hline Fight for position & 0 & 0 \\
\hline Others & 0 & 0 \\
\hline Totally & 35 & 100 \\
\hline
\end{tabular}

Sources: developed by the authors based on SILMED's medical staff survey.

The results of assessing the causes and nature of conflicts in SILMED showed that $40 \%$ of respondents don't talk to each other during the conflict, 34\% - stated that they actively argue with each other during the conflict, $29 \%$ - complain to managerial authority, and $11 \%$ - decline their duties. Therefore, it suggests that most conflicts in SILMED are passive because employees do not talk to each other during the conflict (Table 3). Besides, the main cause of conflicts in a private clinic is work misarrangement, incompetent managers, low sociability of some employees.

Table 3. Conflict characteristics

\begin{tabular}{lcc}
\hline \multicolumn{1}{c}{ Conflict characteristics } & $\begin{array}{c}\text { Number of } \\
\text { respondents }\end{array}$ & $\%$ \\
\hline Employees don't speak & 14 & 40 \\
Employees raise voice at each other & 3 & 9 \\
Employees decline their duties & 4 & 11 \\
Employees don't work to protest & 1 & 3 \\
Employees criticize the managerial authority & 2 & 6 \\
Employees conflict with each other & 12 & 34 \\
Employees plot & 2 & 6 \\
Employees submit a resignation notice & 0 & 0 \\
Employees complain to managerial authority & 10 & 29 \\
\hline
\end{tabular}

Sources: developed by the authors based on SILMED's medical staff survey.

In relation «health worker-patient» conflict system, patients complained about doctors. Doctors identified the main reasons for claims, such as complications and deterioration of health after treatment, incomplete information about changes in paid medical services, and conflicting views on treatment. It stands to note that the conflict between doctor and patient is mainly caused by mood or incompatibility of the patient and the doctor tempers. Thus, it is difficult to overcome during the first visits while they both do not expect problems in interaction.

However, doctors of a private clinic identified several ways to resolve conflicts with patients as follows: changing the medical institution; improving organizational issues; providing complete information about the cost of services and their changes; explaining to the patient that they provide treatment, not service; paying attention to the visit duration, diagnosis, etc.

This study provides a questionnaire consisted of 25 open and closed questions. The survey sample is 70 patients (visitors), including men and women of different age. Thus, the findings showed that one-third of respondents conflicted with doctors. In turn, Table 4 demonstrates the analysis of results determining the most popular conflict cases from patients' prospects. 
Table 4. The most common conflict causes in relation «health worker-patient» (by employees self-assessment)

\begin{tabular}{|c|c|}
\hline Cases & $\%$ \\
\hline Inattention in receiving information on paid medical services & $20 \%$ \\
\hline Complications, deterioration of health & $25 \%$ \\
\hline Ineffective treatment & $17 \%$ \\
\hline Non-meeting the doctor's requirements and recommendations & $14 \%$ \\
\hline
\end{tabular}

Sources: developed by the authors based on SILMED's medical staff survey.

Therefore, the obtained results allowed concluding that the most common causes of conflicts between doctors and patients were non-meeting the doctor's requirements and recommendations caused complications and deterioration of health, as well as inattention in receiving information. Table 5 demonstrates the answer to the question «What from the following could be the case for conflict between patient and doctor?»

Table 5. The respondents' responses concerning the main conflict cases

\begin{tabular}{lc}
\hline \multicolumn{1}{c}{ Responses options } & $\%$ \\
\hline Doctor inexperience & $13 \%$ \\
Inattention in receiving information on paid medical services & $20 \%$ \\
Complications and deterioration of health & $25 \%$ \\
Delivering prohibited paid medical services & $3 \%$ \\
Ineffective treatment & $17 \%$ \\
Non-meeting the doctor's requirements and recommendations & $14 \%$ \\
Inefficiencies of legal base of medical institutions & $10 \%$ \\
Doctor's personal dislike to patient & $25 \%$ \\
Everything is good enough & $12 \%$ \\
\hline
\end{tabular}

Sources: developed by the authors based on SILMED's medical staff survey.

Table 5 shows that $13 \%$ of respondents identified doctor inexperience as a possible conflict cause. Herewith, most of the respondents (75\%) think that the doctor's rudeness couldn't cause disagreement between the patient and the doctor. However, some of the respondents faced this problem in SILMED. Thus, they identified this factor as a possible conflict cause. On the other hand, both women $(22 \%$ of respondents) and men (28\% of respondents) considered complications or deterioration of health as possible conflict causes between doctors and patients. Besides, patients inculpated that the cause of health complications is the medical activity inefficiencies, the doctor incompetency to make a diagnosis, direction and course of treatment. $13 \%$ of men and $21 \%$ of women chose the ineffective treatment as a possible conflict cause with the doctor. In turn, most men (95\%) and women (98\%) believed that rejection of delivering prohibited paid medical services couldn't cause conflict.

It stands to identify that $30 \%$ of interviewed women and $22 \%$ of men conflicted with a doctor of the private medical clinic at least once. Thus, according to both parties to the conflict (doctor and patient), the main conflict causes between doctors and patients in SILMED were ineffective treatment, complications and deterioration of health, Non-meeting the doctor's requirements and recommendations, inattention in receiving information.

The results of a survey of doctors and patients allowed concluding the conflict presented in private healthcare practice. Therefore, the conflict management system in private medicine should minimize the conflict probability, focus on the medical treatment quality and service price, and develop moral codes for doctors in private medical institutions. Indeed, handling mentioned above issues requires major efforts to improve the legal literacy of medical staff and patients. It is essential to provide the information and 
methodological support considering the specifics of a particular medical institution. Besides, it is necessary to make a pact between the patient and clinic to establish their further relationship. Herewith, its basic requirements must be in open access to clients.

Moreover, at the consultation, the medical worker should persuade the patient to comply with all his requirements to maintain or improve one's health. Besides, if necessary, the doctor may ask the patient for proof of following the medical prescription. Furthermore, the findings showed that conflict avoidance in the conflict management system is methodologically incorrect and nearly unrealistic. Thus, transition to a patient-oriented system of relations in health care requires intensification of the positive conflict function based on a collegial model of the relationship between doctor and patient. In turn, other relationship models contain risks of conflict situations intensification.

Conclusions. This study identified the features of doing business and developing private clinics. The authors considered the conflict management specifics in health care. The obtained results of the questionnaire in private medical institutions allowed identifying the leading conflict causes between doctors and patients such as complications, deterioration of health; ineffective treatment; non-meeting the doctor's requirements and recommendations by the patient; inattention in receiving information on paid medical services. The findings showed that the doctor and the patient could cause growing controversy. In turn, the results confirmed that government and its policies partially influence the conflict between doctors and patients in private clinics. Besides, the work peculiarities of private medical institutions could provoke conflict between doctors and patients. Both doctors and patients face the legal legislation gaps of private medical institutions. Thus, patients are often inattentive and don't pay attention to all service terms what could cause controversy. Moreover, it was found that patients faced ineffective treatment and disease complication after treatment in the private medical institution.

The study suggests measures to reduce conflicts and avoid further contradictions as follows: in cases of treaty-making with a patient, the doctor must make the patient aware of the contract terms and attend to the patient's attention signing the contract; at the consultation, doctors should persuade the patient to comply with all requirements.

Author Contributions: conceptualization, methodology, software, validation, formal analysis, investigation, resources, data curation, T. T.; writing-original draft preparation, T. T., lu. M.; writing-review and editing, lu. M., K.L. and E. L.; visualization, lu M., K.L.; supervision, project administration, lu. M.

Funding: This research received no external funding.

\section{References}

Baldwin, D., \& Daugherty, S. (2008). Interprofessional conflict and medical errors: Results of a national multi-specialty survey of hospital residents in the US. Journal of Interprofessional Care, 22, 573-586. [Google Scholar] [CrossRef]

Blanco-Donoso, L. M., Moreno-Jiménez, J., Hernández-Hurtado, M., Cifri-Gavela, J. L., Jacobs, S., \& Garrosa, E. (2021). Daily Work-Family Conflict and Burnout to Explain the Leaving Intentions and Vitality Levels of Healthcare Workers: Interactive Effects Using an Experience-Sampling Method. International Journal of Environmental Research and Public Health,18(4),1932. [Google Scholar] [CrossRef]

Brown, J., Lewis, L., Ellis, K., Stewart, M., Freeman, T., \& Kasperski, M. (2011). Conflict on interprofessional primary health care teams - can it be resolved? Journal of Interprofessional Care, 25, 4-10. [Google Scholar] [CrossRef]

Bylchenko, O. (2004). Medical ethics and medical deontology: a textbook for medical students, interns / Kharkiv National Medical University. Kharkiv: Tornado, 2004.198 p. [Link]

Chen, S. C., Chiang, Y. H., \& Huang, Y. J. (2017). Exploring the psychological mechanisms linking work-related factors with work-family conflict and work-family facilitation among Taiwanese nurses. The International Journal of Human Resource Management, 28(4), 581-602. [Google Scholar] [CrossRef]

Haraway, D. L., \& Haraway, W. M. (2005). Analysis of the effect of conflict-management and resolution training on employee stress at a healthcare organization. Hospital Topics, 83(4), 11-17. [Google Scholar] [CrossRef]

Kelly, J., \& Al-Rawi, Y. (2021). Recognising, understanding and managing high conflict behaviours in healthcare. Postgraduate Medical Journal, (1144),123-124. [Google Scholar] [CrossRef] 
Kim, S., Bochatay, N., Relyea-Chew, A., Buttrick, E., Amdahl, C., Kim, L., ... \& Lee, Y. M. (2017). Individual, interpersonal, and organisational factors of healthcare conflict: a scoping review. Journal of interprofessional care, 31(3), 282-290. [Google Scholar] [CrossRef]

Korzh, O. Yu. (2013). Self-actualization of future physicians and its formation in the process of independent educational activity. Pedagogy of Creating a Creative Personality in Higher and General Education Schools, 29, 238-243. Retrieved from [Link]

Lymar L. V. (2011). The peculiarities of motivation of medical students for prevention of conflicts with patients during their professional preparation. Herald of Postgraduate Education, 3, 350-357. Retrieved from [Link]

Mochalov, Yu. O. (2014). Prevention of errors and conflicts in the contractual arrangements of medical institutions and insurance companies. Journal of the Deputy Chief Doctor, 2, 48 - 55. Retrieved from [Link]

Piryani, R. M., \& Piryani, S. (2019). Conflict Management in Healthcare. J Nepal Health Res Counc., 16(41), 481-482. Retrieved from [Link

Pitsillidou, M., Farmakas, A., Noula, M., \& Roupa, Z. (2018). Conflict management among health professionals in hospitals of Cyprus. The Journal of Nursing Management, 26(8), 953-960. [Google Scholar] [CrossRef]

Portoghese, I., Galletta, M., Leiter, M.P., Cocco, P., D'Aloja, E., \& Campagna, M. (2017). Fear of future violence at work and job burnout: A diary study on the role of psychological violence and job control. Burnout Research, 7, 36-46. [Google Scholar [CrossRef]

Raykova, E. L., Semerjieva, M. A., Yordanov, G. Y., \& Cherkezov, T. D. (2015). Dysfunctional Effects of a Conflict in a Healthcare Organization. Folia Med (Plovdiv), 57(2), 133-7. [CrossRef] [CrossRef]

Т. Теницька, Сумський державний університет (Україна);

Ю. Мирошниченко, к.е.н., доцент, Сумський державний університет (Україна);

К. Ломія, Кавказький міжнародний університет (Грузія).

Система управління конфліктами в галузі охорони здоров'я

У статті розглянуто шляхи вдосконалення системи управління конфліктами в галузі охорони здоров'я на основі аналізу причин виникнення конфлліктів у приватному медичному закладі. Авторами проаналізовано процес надання медичної допомоги у тріаді «медичний працівник - пацієнт -суспільство». Досліджено причини виникнення конфліктів у галузі охорони здоров'я в системі взаємовідносин «медичний працівник - пацієнт» та «медичний працівник - медичний працівник». Для визначення причин конфоіктів у закладах приватного сектору охорони здоров'я та шляхів їх мінімізації було застосовано методи анкетного збору даних (опитування персоналу та пацієнтів клініки на базі лікувально-діагностичного центру дП «СІЛМЕД», Україна), метод опитування, метод аналізу даних та графічний метод. Базуючись на виявлених проблемах організації системи управління конфлліктами було визначено сутність конфліктних ситуацій, що виникають в приватних медичних закладах. На основі отриманих результатів опитування, авторами були розроблені пропозиції щодо вдосконалення системи управління конфліктами приватного медичного закладу. Таким чином, система управління конфліктами в приватній медицині повинна мінімізувати ймовірність виникнення конфліктної ситуації, акцентувати увагу на відповідність якості лікування і ціни послуги, включати розробку моральних кодексів для лікарів приватних закладів. Встановлено, що для зниження рівня конфліктності в системі взаємовідносин «медичний працівник - медичний працівник» попередження конфоліктів $є$ ефективнішим за їх конструктивне вирішення. Профілактика конфоліктів важлива для успішної діяльності клініки та вимагає менше зусиль, засобів й часу. Для зменшення рівня конфліктності в системі взаємовідносин «медичний працівник - пацієнт» має бути створений договір пацієнта з приватним медичним закладом, який встановлює відносини пацієнта з клінікою та знаходиться у відкритому доступі для клієнтів. Під час консультації, медичний працівник повинен переконати пацієнта дотримуватися всіх рекомендацій щодо збереження або поліпшення здоров'я пацієнта, вимагаючи, за потреби, від пацієнтів клініки докази дотримання протоколу лікування.

Ключові слова: конфлікт, конфлікт «медичний працівник - пацієнт», конфлікт «медпрацівник - медпрацівник», медичні послуги, охорона здоров'я, приватна медицина.

Manuscript received: 21.08 .2020

(C) The author(s) 2020. This article is published with open access at Sumy State University. 